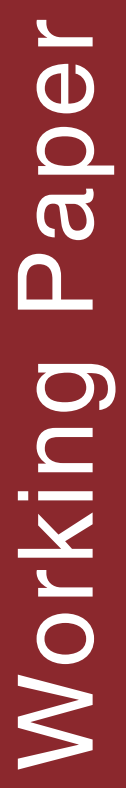

Ian K. Dawson, Andrew Barnes, Ramni Jamnadass, Eric Danquah, Rita H. Mumm, Steve Hoad, Fiona Burnett, lago Hale, Kai Mausch,

Prasad Hendre, Wayne Powell, Cesar Revoredo-Giha 
Breeders' views on the production of new and orphan crops in Africa: a survey of constraints and opportunities

lan K. Dawson, Andrew Barnes, Ramni Jamnadass, Eric Danquah, Rita H. Mumm, Steve Hoad, Fiona Burnett, lago Hale, Kai Mausch, Prasad Hendre, Wayne Powell,

Cesar Revoredo-Giha 


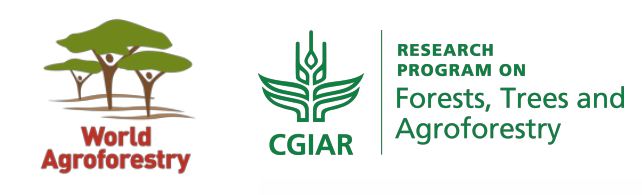

\section{Ґ ILLINOIS}

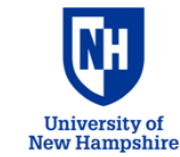

\section{Correct citation:}

Ian K. Dawson, Andrew Barnes, Ramni Jamnadass, Eric Danquah, Rita H. Mumm, Steve Hoad, Fiona Burnett, lago Hale, Kai Mausch, Prasad Hendre, Wayne Powell, Cesar Revoredo-Giha. 2019. Breeders' views on the production of new and orphan crops in Africa: a survey of constraints and opportunities. ICRAF Working Paper No. 296. World Agroforestry. DOI: http://dx.doi.org/10.5716/WP19007.PDF

Published by World Agroforestry

United Nations Avenue PO Box 30677, GPO 00100 Nairobi, Kenya

Tel: $+254(0) 207224000$, via USA +16508336645

Fax: +254(0)20 7224001, via USA +1 6508336646

Email: icraf@cgiar.org

Internet: www.worldagroforestry.org

(C) World Agroforestry 2019

Working Paper No. 296

The views expressed in this publication are those of the authors and not necessarily those of World Agroforestry.

Articles appearing in this publication series may be quoted or reproduced without charge, provided the source is acknowledged. 


\section{About the authors}

Ian Dawson, Ramni Jamnadass, Kai Mausch and Prasad Hendre work for World Agroforestry (ICRAF). Ian Dawson also works for Scotland's Rural College (SRUC), Edinburgh, Scotland.

Andrew Barnes, Steve Hoad, Fiona Burnett, Wayne Powell and Cesar Revoredo-Giha work for SRUC.

Eric Danquah works for the University of Ghana, Accra and leads the West Africa Centre for Crop Improvement (WACCI).

Rita Mumm and lago Hale are part of the instructor team of the University of California Davis African Plant Breeding Academy (AfPBA). Rita Mumm is based the University of Illinois, Urbana, and lago Hale at the University of New Hampshire, Durham - both in the United States.

The authors are interested in research and capacity building related to crop and food production and consumption, including of annual and perennial new and orphan crops. The authors include plant breeders, agronomists, economists and behavioural change researchers. 


\begin{abstract}
New and orphan crops, which in the past have received only limited research attention, have great potential to support healthy diets in Africa. However, limited systematic data are available on the constraints to production faced by these annual and perennial crops, and the possible opportunities for intervention to remove critical barriers. We report on the results of a survey of African plant breeders to begin identifying constraints to crop production, guide the direction of crop genetic improvement activities and identify appropriate agronomic management interventions. The survey was completed by 67 plant breeders affiliated with institutions in 18 African countries and focused on crops prioritized for genetic improvement by the African Orphan Crops Consortium (AOCC). Of the survey respondents, 38 worked on new or orphan crops on the AOCC crop list. In total, respondents provided specific data on 30 of these crops. We discuss the findings of the survey, which indicate that pest and disease attacks, and lack of access to - or availability of - high-quality planting material are important barriers to be addressed in enhancing production. Other insights from the survey include the differentiation of responses based on the part of the crop used for food, and breeders' views on the future importance of these plants. These results and additional findings are elaborated along with opportunities for future research to delve deeper into production constraints and solutions for new and orphan crops.
\end{abstract}

\title{
Keywords
}

African Orphan Crops Consortium, African plant breeders, agronomic management, crop production constraints, genetic improvement, new crops, orphan crops 


\section{Acknowledgements}

This Working Paper is based on responses to an online survey on new and orphan crop production constraints and opportunities in Africa. The survey was completed by 67 plant breeders (or other "crop domesticators") working in Africa, the majority of whom are listed in appendix 2 (a number of respondents chose to remain anonymous). We are very grateful for the contributions of all respondents. As authors, we take full responsibility for the interpretation of the survey responses and for the final text of this study, including any deficiencies it may contain.

Our thanks also to Hope Traficanti (ICRAF) for editorial support in the production of this study.

SRUC authors gratefully acknowledge Global Challenge Research Funding for research on orphan crops through project BB/P022537/1 (Formulating Value Chains for Orphan Crops in Africa, 2017-2019, Foundation Award for Global Agriculture and Food Systems). The current paper was an initiative of this project.

ICRAF authors gratefully acknowledge the support of the CGIAR's funding partners for their work (http://www.cgiar.org/about-us/ourfunders/).

AfPBA, WACCI and the African Orphan Crops Consortium (AOCC) gratefully acknowledge the significant financial and in-kind contributions of their many partners. 


\section{Table of Contents}

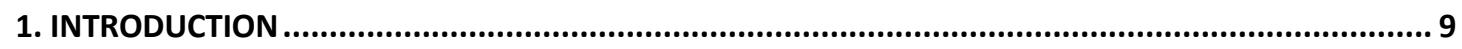

2. METHODS

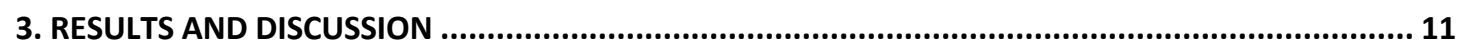

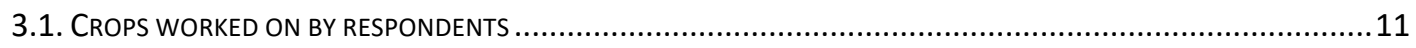

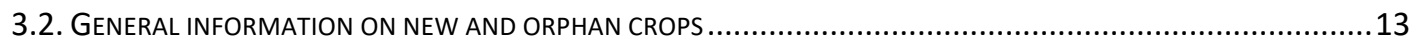

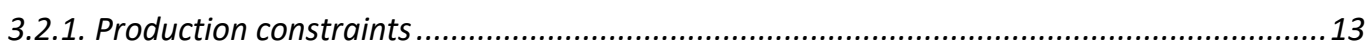

3.2.2. Other (non-production) constraints ............................................................................. 14

3.2.3. New and orphan crop future importance ................................................................... 15

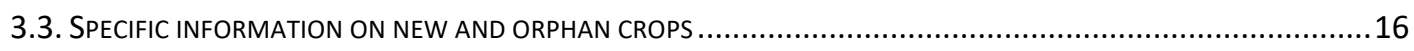

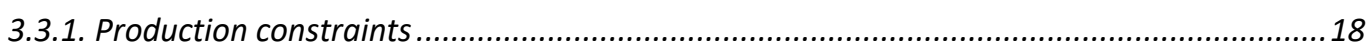

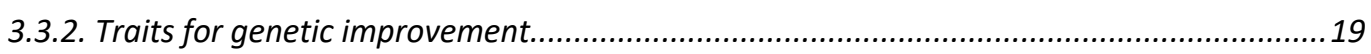

3.3.3. Agronomic management interventions ...................................................................2 20

3.3.4. Production constraints, traits for genetic improvement and management interventions by

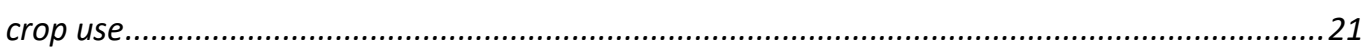

3.3.5. Production constraints, traits for genetic improvement and management interventions for the most frequently mentioned crops................................................................................. 23

3.3.6. Likelihood of success of genetic improvement and management interventions ................24

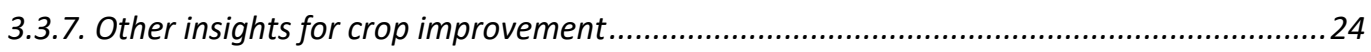

3.3.8. Particular challenges and opportunities presented by climate change .............................25

3.3.9. Particular harvesting and processing challenges.......................................................25

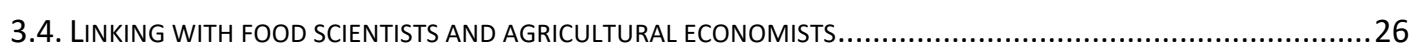

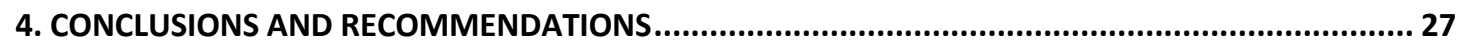

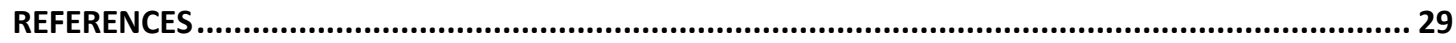

APPENDIX 1. ONLINE QUESTIONNAIRE USED TO OBTAIN INFORMATION FROM PLANT BREEDERS. 31 APPENDIX 2. LIST OF SURVEY RESPONDENTS WHO WISHED TO BE IDENTIFIED (BY COUNTRY) ....... 38

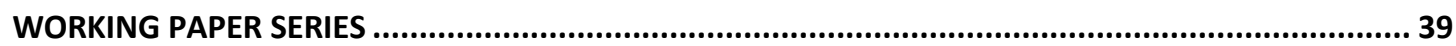




\section{Figures and tables}

Figure 1. Crops worked on by survey respondents .................................... 12

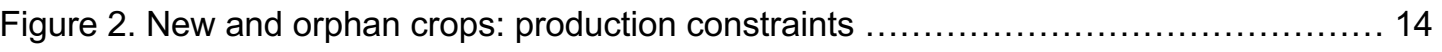

Figure 3. New and orphan crops: other constraints ......................................... 15

Figure 4. New and orphan crops: relative importance in 20 years' time .....................16

Figure 5. AOCC crops for which breeders gave responses ................................ 17

Figure 6. Specific new and orphan crops: production constraints ......................... 19

Figure 7. Specific new and orphan crops: traits for genetic improvement ....................20

Figure 8. Specific new and orphan crops: management interventions .......................21

Figure 9. Specific new and orphan crops: likelihood of success of interventions ............. 24

Table 1. Priority production constraints, traits for genetic improvement and management interventions for four AOCC crops. 


\section{Acronyms}

AfPBA African Plant Breeding Academy, University of California Davis

AOCC African Orphan Crops Consortium

ICRAF World Agroforestry

SRUC Scotland's Rural College

WACCI West Africa Centre for Crop Improvement 


\section{Introduction}

New and orphan crops, which in the past have received only limited research attention, have great potential to support the nutrition of malnourished African consumers, and the productivity, sustainability and stability of African farming systems. Wider recognition of this potential has increased attention on these annual and perennial food plants in recent years (Economist, 2017). An agenda for research on these plants was recently detailed in another ICRAF working paper related to the current study, which was authored by scientists from ICRAF, SRUC and other institutions (Dawson et al., 2018).

The African Orphan Crops Consortium (AOCC) is a recent initiative on Africa's new and orphan crops. By applying new genomic methods to enhance crop improvement, AOCC (2019) is helping to mainstream 101 new and orphan crops of nutritional importance to African consumers into sub-Saharan African food systems. The University of California Davis African Plant Breeding Academy (AfPBA), an initiative of AOCC, supports the application of DNA-based approaches to crop genetic improvement by training practicing African plant breeders in the application of genomic information to achieve breeding objectives (AfPBA, 2019). In addition, the West Africa Centre for Crop Improvement (WACCI) supports training to $\mathrm{PhD}$ level of African plant breeders in the application of advanced genetic improvement approaches in plant breeding (WACCI, 2019).

To advance the development of improved new and orphan crop cultivars, it is important to understand the constraints faced in the production of these crops, and the opportunities for removing these barriers. This working paper reports on a survey aimed at compiling such information from among African plant breeders. While breeders are only one stakeholder group in crop promotion, they are perhaps in the best position to grasp sector-wide concerns that can inform improved crop development.

The breeders chosen to participate in the current survey included alumni of the AfPBA and WACCI initiatives, as well as a small group of other crop domestication experts with whom the authors currently work with or have worked with in the past.

The survey approach involved asking breeders to fill out an online questionnaire on new and orphan crops. The results of the survey, described below, will help to integrate new and orphan crop breeding activities into wider mainstreaming efforts for these crops. 
We first describe the methods used for the survey, then provide the broad results for new and orphan crops, followed by the results for specific AOCC crops, including findings stratified by the part of the crop used for food. We then highlight linkages indicated by the survey between breeders and food scientists and economists that are relevant for mainstreaming new and orphan crops into food systems, and conclude with final remarks and recommendations for future work.

\section{Methods}

We emailed 117 plant breeders or other "crop domesticators" (hereafter also referred to as breeders) working in Africa, asking them to complete an online survey using contact lists for alumni of the AfPBA and the WACCI initiatives. Contacts otherwise known to the authors who were not AfPBA or WACCI alumni included several scientists who currently work on - or have worked on in the past - perennial crop domestication at ICRAF. This is highly relevant since a number of the tree species that ICRAF researches are on the AOCC list of 101 new and orphan crop plants.

The email sent to breeders asked then to complete an online survey via a hyperlinked questionnaire available through Snap (www.snapsurveys.com). The survey, provided in appendix 1 and outlined in the Results and discussion section of this paper, was designed to collect general information on constraints to new and orphan crop production, as well as specific production constraints and opportunities for individual plants on the AOCC list. The questionnaire covered traits for genetic improvement and potential management interventions during production. We also asked how likely breeders thought success would be for different interventions, and for their other insights on crop improvement. Respondents were requested to indicate particular challenges and opportunities for new and orphan crops posed by climate change, as well as the particular harvesting and processing challenges associated with these plants. Mostly free text responses were collected and then classified by common themes.

Recognizing the importance of inter-disciplinary action for effective crop promotion, the questionnaire also sought information on the linkages between plant breeders completing the survey and food scientists and economists. This approach was designed to elicit insights into how production research on new and orphan crops is linked with wider food system interventions to support crop mainstreaming.

The survey was distributed on 27 March 2018 and was closed on 27 May 2018, after which responses were synthesized. 


\section{Results and discussion}

Nearly all of the 67 respondents who contributed information to the survey self-identified as plant breeders; 50 of the respondents are listed in appendix 2 (the other 17 respondents preferred to remain anonymous). The response rate of 67 out of 117 breeders (57\%) was very high for this type of survey, which may reflect the fact that the AfPBA and WACCI coordinators (Rita Mumm and Eric Danquah, among the authors of this working paper) directly communicated with their alumni to encourage their participation.

Based on the total of 67 respondents, 18 African countries were represented by contributors' institutional affiliations, with Nigeria the largest contributor (ten respondents), followed by Niger (eight), Burkina Faso (seven), and then Cameroon, Kenya and Ghana (all with six respondents). The results of specific survey questions are summarized below, following the structure of the questionnaire. The (anonymous) raw data collected through the survey are available upon request (from lan Dawson: iankdawson@aol.com).

\subsection{Crops worked on by respondents}

The 67 respondents to the survey mentioned 73 crops that they currently worked on or had worked on in the past (see figure 1). Of all the respondents, 38 indicated that they currently or previously worked on new or orphan crops on the AOCC list. The 36 plant species on the AOCC list that were covered by respondents comprised 17 generally grown as annuals and 19 grown as perennials (of which the majority were tree species). Only two out of the group of 38 respondents that worked on AOCC-listed new and orphan crops worked exclusively on these crops; 15 currently or had in the past also worked on one or more of the major staples of rice, maize, wheat, potato and soybean. This can be considered advantageous for new and orphan crop work since it suggests that there is scope for cross applying methods from major crops that receive heavier investments than new and orphan crops. On average, respondents mentioned that they had worked with three crops, indicating additional potential for crossapplication of breeding approaches. 
Figure 1. Crops worked on by survey respondents.

The number of respondents working on each crop is indicated on the x-axis. Crops with blue bars are on the AOCC list.

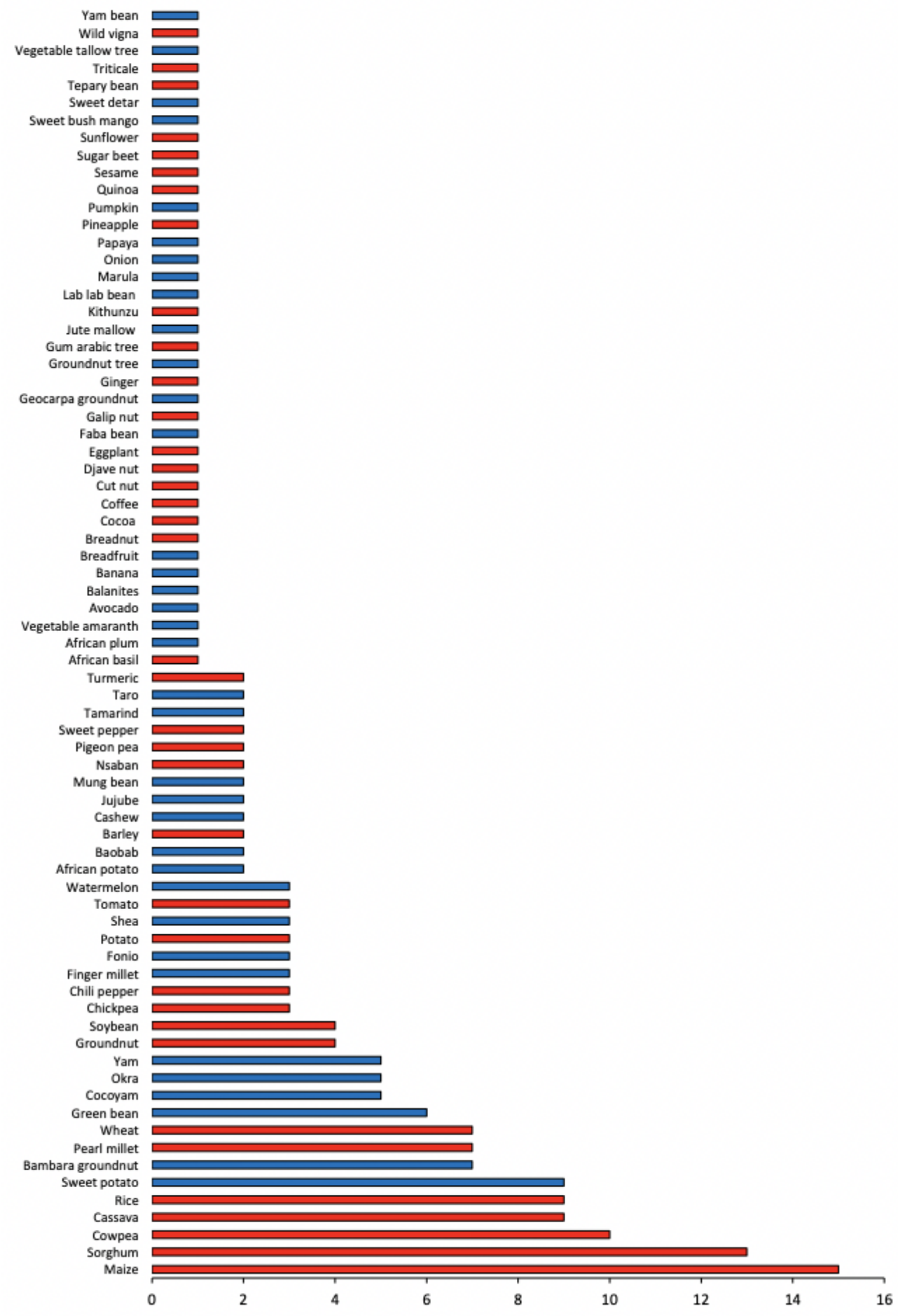




\subsection{General information on new and orphan crops}

\subsubsection{Production constraints}

Surveyed breeders were asked to list what they considered to be the most important constraints to new and orphan crop production in general (non-crop-specific responses); breeders were requested to list up to three constraints. The 67 respondents to the survey provided 171 responses related to production, including constraints pertaining to agronomic management, genetic deficiencies and access to inputs (see figure 2). Crop pest and disease attacks were the most frequently mentioned genetic or management constraint, followed by drought. Lack of access to - or unavailability of -suitable high-quality planting material was by far the most frequently mentioned input constraint, followed by lack of knowledge of how to produce crops.

Yield potential ('Yield' in figure 2) was not frequently mentioned as a limiting production factor, but this may be because an element of productivity is implicit within the requirement for highquality planting material: as already noted, quality planting material was frequently indicated as a priority by breeders (i.e. "high quality" as in genetically improved planting materials for better yields). The strong emphasis on access to and availability of high-quality planting material is consistent with the situation for major crops in Africa, where farmers' inability to access improved germplasm is recognized as a common problem (Walker et al., 2014). If high-quality varieties of major crops with significant investment programmes are still failing to reach farmers, we would expect the situation for new and orphan crops to be worse, consistent with the survey findings. However, this cited need could also be a result of quality issues related to poor germination or poor seed/propagule health of the available planting materials. Especially for those new and orphan crops propagated vegetatively to distribute plant parts (versus seed propagation), it could be a matter of problems with viral infections and the need to receive clean clonal planting materials.

Details of breeders' views on planting material access and availability were not elicited in this survey because specific questions that would allow the further description of bottlenecks in planting material supply were not included (see appendix 1). Gaining a more detailed understanding of access and availability - to delineate quality, yield and other issues - should be a priority for follow-up surveys. Likewise, the current survey did not elicit specific information on pest and disease pressures from breeders (many breeders described these pressures only in general statements). Exploring this issue in the future will be important, 
since varied genetic responses are involved in combating different pest and disease pressures.

Figure 2. New and orphan crops: production constraints.

In the key, in black type are genetic/management constraints; in red type are input constraints. Both genetic and management interventions may be applied to address a particular constraint. For example, 'Weeds', indicating a problem with weed presence, might be addressed through crop canopy design that excludes weeds from crops or through improved weeding approaches. The input constraints indicated also interact with management regimes, so the given classification represents an approximation.
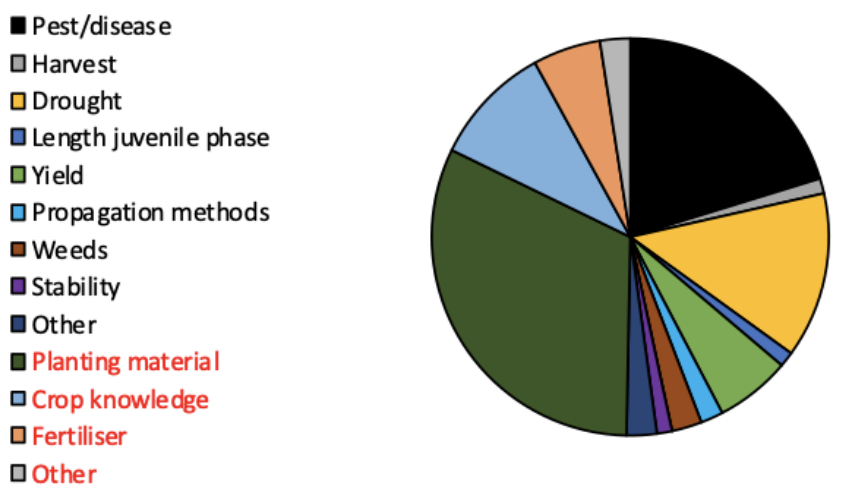

\subsubsection{Other (non-production) constraints}

Surveyed breeders were asked to provide their views on the most important other (nonproduction) constraints that limit the use of new and orphan crops in Africa, again considering these crops as a general category (non-crop-specific responses); breeders were again asked to list up to three constraints. The 67 survey respondents provided 116 relevant nonproduction-related responses, which are summarized in figure 3 . The absence of consumer knowledge on crops was considered to be the most important non-production constraint, followed by post-harvest and processing issues.

A less-mentioned but still common concern was the absence of supportive policies for new and orphan crops. Another important concern was the absence of markets, which can be grouped with low product-value concerns ('Value' in figure 3) and value chain-development problems. A further constraint related to markets is difficulty in scaling production in line with market opportunities. This latter constraint, which relates to the critical mass needed for 
commercial success, is an interesting issue that has not received adequate consideration in many new and orphan crop promotion programmes with a philosophy of "starting small". In fact, the survey results support the view that starting very small may not be an option for market engagement - at least for some crops.

Figure 3. New and orphan crops: other constraints.
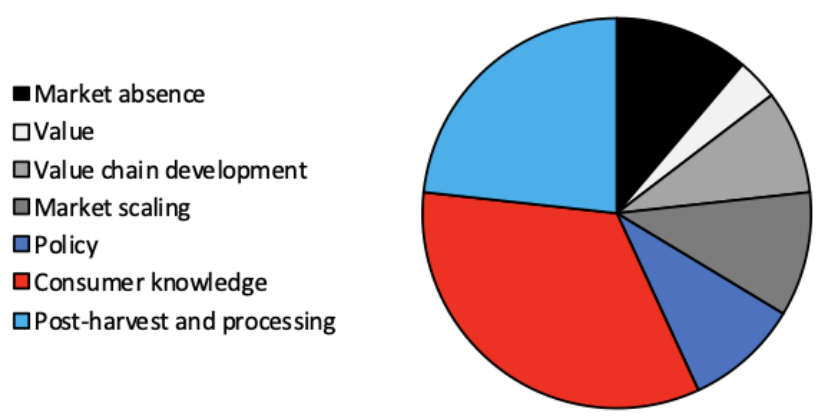

\subsubsection{New and orphan crop future importance}

When asked to rate the relative importance of new and orphan crops as foods in Africa 20 years from now, most of the 67 survey respondents reported that they would be more important (see figure 4). Frequent reasons given were that these crops are better adapted to Africa's production environments and that there is renewed interest on the continent in the nutritional diversity of crop production. Breeders' responses thus fit with polices such as those presented in the Malabo declaration (African Union, 2014), which seek to diversify the African continent's food systems to support human nutrition and resilient food supply.

Several breeders' responses indicated that work is required to support the greater use of new and orphan crops, and that without this investment, less-nutritious, existing staples foods would continue to dominate in Africa. This view is consistent with analyses of current trends in food production and usage globally. For example, the assessment of Khoury et al. (2014) indicated a trend between 1961 and 2009 towards a narrower range of calorie-rich but otherwise nutrition-poor staples worldwide.

Of the breeders who responded to the survey, 32 were alumni of the AfPBA, which specifically encourages new and orphan crop breeding, so their preference for indicating the increased importance of new and orphan crops might be expected. Their responses overall, however, did not differ substantially from those of other breeders included in the survey (e.g. 
for AfPBA alumni, 21 of 32 responders indicated that new and orphan crops will be more important in 20 years' time, compared to 18 of 35 other responders). But caution should be used in drawing conclusions on the future importance of new and orphan crops from the surveyed breeders. Although the sample is relatively large and diverse, it is not fully representative; wider sampling is recommended to explore this issue further.

Figure 4. New and orphan crops: relative importance in 20 years' time.

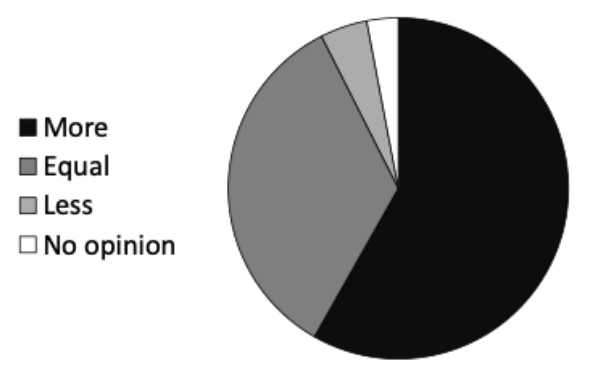

\subsection{Specific information on new and orphan crops}

When presented with a list of the $101 \mathrm{AOCC}$ new and orphan crops, 53 of the 67 breeder respondents to the survey were able to give specific information about individual crops. Each of these respondents was permitted to provide information on up to five crops on the AOCC list. In total, 65 responses on 30 different crops were received. Each respondent on average commented on only 1.2 crops, which is a low response rate when considering that up to five crops could be commented on. This supports the view that national programmes in African countries are not heavily focused on orphan crops. It may also indicate problems with the design of our survey (as addressed further below). Of the 30 crops commented on, 18 are annuals and 12 are perennials. For 11 of these crops, the primary product used by humans for food is known to be the seed (grain or nut), followed by the root in eight cases, the fruit in seven cases and the leaf in four cases.

The crops for which specific responses were provided by breeders are indicated in figure 5 . The crop receiving the greatest number of responses was Bambara groundnut (11 responses), followed by okra (five), fonio (four) and finger millet (four). All of these crops were indicated as subjects of work by several breeders participating in the survey (see figure 1), so it is not surprising that these crops were commented on multiple times. For six AOCC crops African nightshade, bitter yam, elephant ear, lima bean, roselle and spider plant - breeders were able to give crop-specific responses even though no breeders had indicated that they 
worked on these crops (compare figure 5 with figure 1). This indicates that breeders have knowledge that extends beyond the crops on which they work directly.

Conversely, none of the 67 breeders sampled provided specific responses for 12 AOCC crops that they had earlier indicated they work on or had worked on in the past (again, compare figures 5 and 1). These crops were African potato, avocado, balanites, banana, faba bean, groundnut tree, jute mallow, marula, papaya, pumpkin, sweet bush mango and sweet detar. This may indicate that breeders were not able to fully understand the survey design. For example, some of the 67 breeders may not have been able to determine how to comment on specific AOCC crops. In addition, after commenting on one crop, some of the 53 breeders that did provide specific responses on AOCC crops may have found it difficult to comment on additional crops. This potential survey design issue should be considered before any future use of the survey with other breeders.

Figure 5. AOCC crops for which breeders gave responses.

The number of respondents for specific crops is indicated on the $x$-axis. Entries with green bars were not mentioned by breeders as crops they worked on (see figure 1).

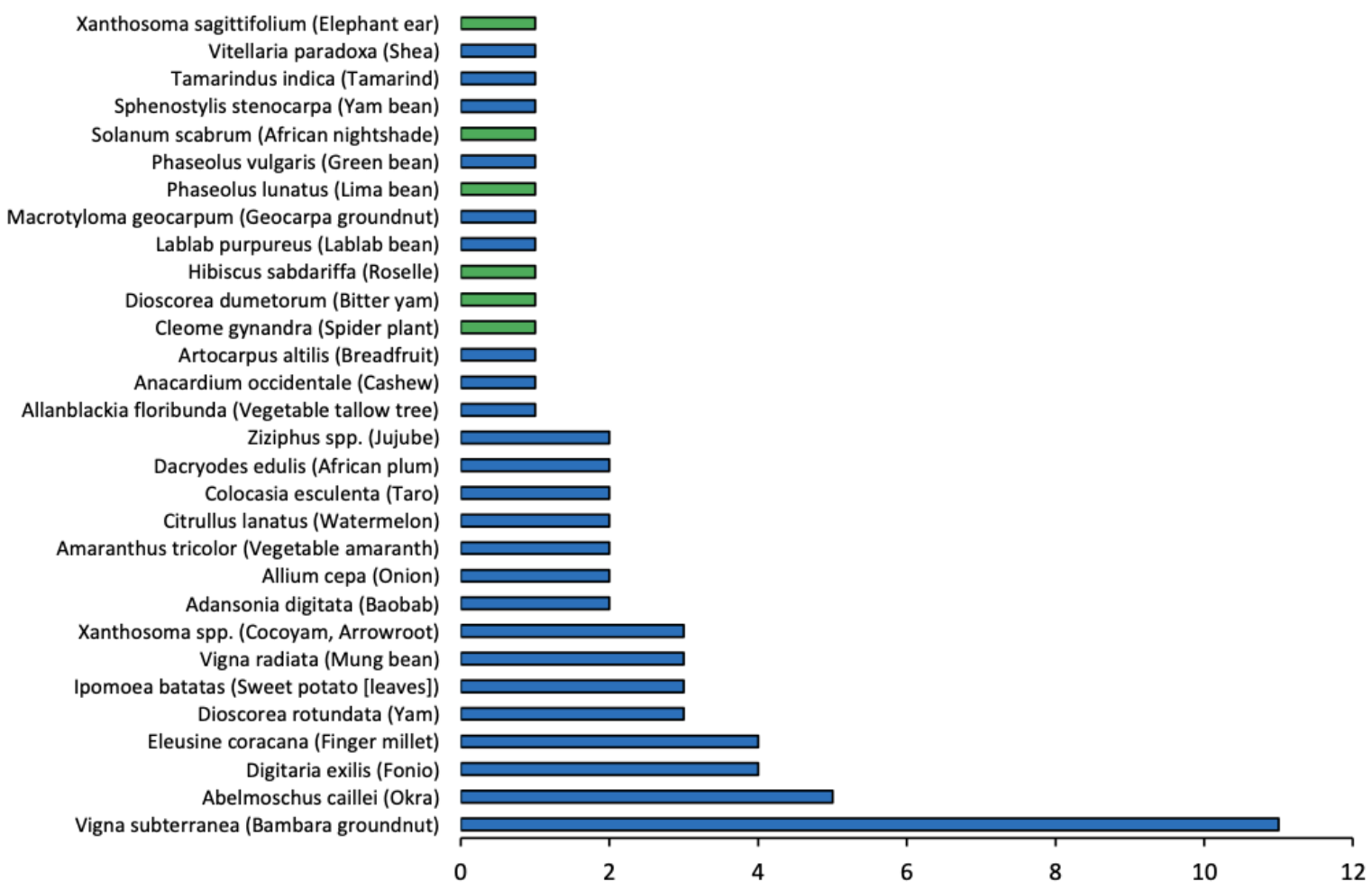




\subsubsection{Production constraints}

The survey asked breeders to list what they considered to be the three most important production constraints faced by African farmers for specific AOCC crops they commented on. A review of all 181 relevant (production-related) responses from the 53 responding breeders across AOCC crops, without correcting for the different representations of the various crops (see figure 5), indicated a number of important production constraints, as shown in figure 6. The overall picture was similar to that for new and orphan crops in general (see figure 2), with pest and disease attacks the most frequently mentioned genetic or management constraint, and lack of access to (or unavailability of) suitable high-quality planting material the most frequently mentioned input constraint.

However, there were interesting differences between the general and specific responses on new and orphan crop production constraints obtained by the survey. One notable difference was the greater mention of harvesting problems for specific AOCC crops. This may indicate that these concerns are at the forefront of breeders' attention when considering crop-specific constraints in detail. Another interesting difference was that relatively less (although still significant) attention was given to access to and availability of high-quality planting material for specific AOCC crops. This could reflect the fact that the new and orphan crops being commented on specifically by breeders are being worked on at least to some extent, and respondents may be involved in producing and distributing planting materials of improved cultivars of these crops to farmers. As already noted in section 3.2.1, further delineation of key supply issues will require additional questioning of breeders. 
Figure 6. Specific new and orphan crops: production constraints.

In the key, in black type are genetic/management constraints; in red type are input constraints. See figure 2 for more information.

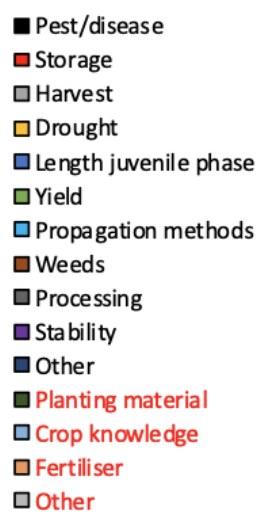

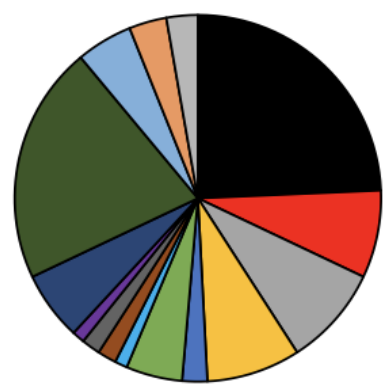

\subsubsection{Traits for genetic improvement}

The survey questionnaire asked breeders to list what they considered to be up to the three most important traits for genetic improvement for specific AOCC crops they were commenting on. A compilation of all 179 relevant responses from the 53 responding breeders, without correcting for the different representations of the various crops (see figure 5), indicated a number of important traits for genetic improvement (figure 7). Breeders most often mentioned pest and disease tolerance or resistance as important, consistent with pest and disease problems being most mentioned as important production constraints (figure 6). As indicated in section 3.2.1, exploring this trait category in more detail will be important in the future.

After pest and disease tolerance and resistance, yield was the next most mentioned trait category for genetic improvement. Improvement in traits to make harvest easier was mentioned fifth most often. In this category, three responses called for reduced grain shattering and two called for improved threshability. The 'Other' category in figure 7, which covered responses that could not be clearly classified into more frequently cited specific trait categories, included two responses that called for larger seed size. This could also relate to crop harvestability (larger seed are easier to harvest) or it may refer to a need for improvements in yield (or to both harvestability and yield). Another two responses in the 'Other' category mentioned the need for a change in seed colour. This appears to be one of 
the few examples in the survey of breeders' responses relating directly to consumers' preferences.

Figure 7. Specific new and orphan crops: traits for genetic improvement.
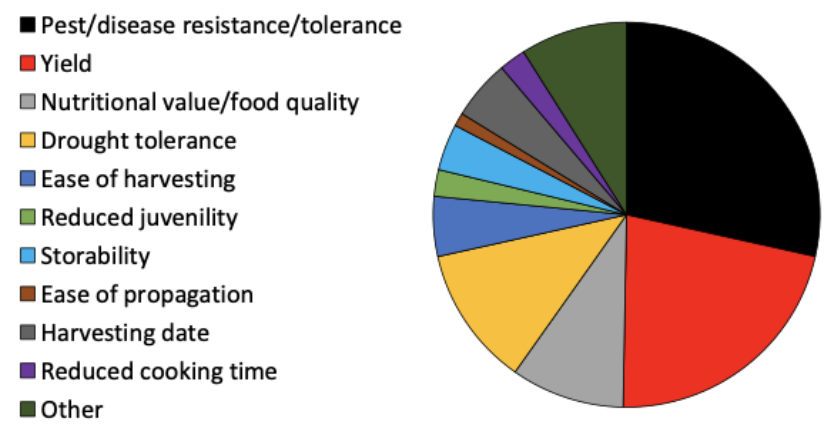

Along with questions on traits for genetic improvement, breeders were asked if they were aware of breeding programmes on the specific AOCC crops that they were commenting on. There were 36 "yes" responses to this question, indicating several existing breeding programmes for a range of new and orphan crops. Further examination of responses indicated that breeders' knowledge of breeding programmes varied: for eight crops, both "yes" and "no" responses were recorded (these crops were Bambara groundnut, cocoyam, fonio, finger millet, jujube, okra, onion and vegetable amaranth). This suggests the need for more communication among breeders about current breeding efforts. It is also possible that the question on breeding programmes was misinterpreted by breeders as referring to programmes in their own countries, although this was not intended (the question: "Are you aware of a breeding or other genetic improvement programme[s] for this crop?" did not make any reference to country - see appendix 1.)

\subsubsection{Agronomic management interventions}

The survey asked breeders to list up to the three most important agronomic management interventions to support the African production and use of specific AOCC crops they were commenting on. A review of all 111 relevant responses of the 53 responding breeders across specific AOCC crops, without any rebalancing of calculations to account for the different representations of the various crops in the results (see figure 5), indicated several recommended interventions (figure 8 ). Breeders most frequently mentioned the need for soil fertilization, followed by pest and disease control measures. The reporting of pests and diseases as the most mentioned production constraint (as stated in section 3.3.1), but control 
as only the second most frequently mentioned management intervention, suggests that breeders see plant breeding as the more appropriate pathway to address pest and disease issues. (Pest and disease tolerance and resistance was the most often mentioned trait category for genetic improvement, as stated in section 3.3.2.) However, it is clear that both genetic improvement and agronomic interventions are considered by breeders to be important to address pest and disease problems. The same applies to yield improvements, if agronomic management of soil fertilization is seen in the context of yields (i.e. fertilization is needed to improve yields as a complementary pathway to breeding).

Improvements in planting methods ('Planting/establishment' in figure 8) and in the seasonal timing of management interventions (such as planting and weeding) were the third and fourth most frequently mentioned interventions by breeders respectively, while the need for improvements in harvesting was the fifth most mentioned management intervention.

The issue of seasonal timing is particularly interesting because it affects the allocation of rural labour to field activities. As African countries' populations urbanize, the ability to allocate labour could be a significant constraint to new and orphan crop production (Kessides, 2005). Seasonal timing also affects cultivar maturity, crop rotations and water requirements.

Figure 8. Specific new and orphan crops: management interventions.
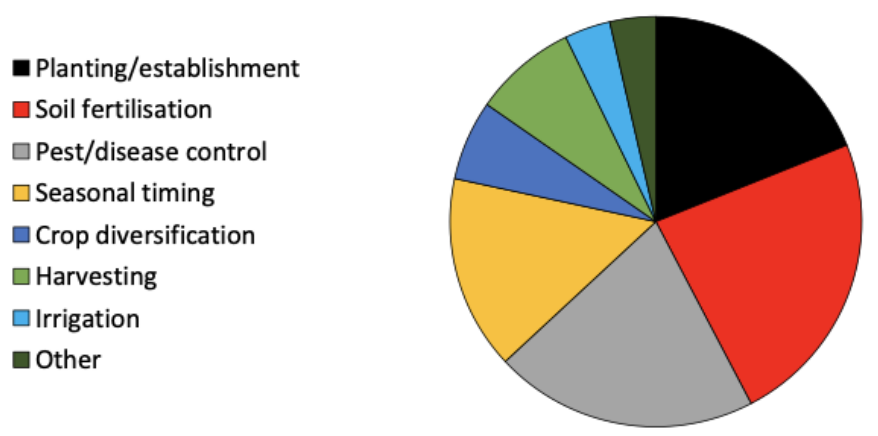

\subsubsection{Production constraints, traits for genetic improvement and management interventions by crop use}

Considering breeders' responses related to specific AOCC crops (detailed in sections 3.3.1 to 3.3.3) based on categorizing these plants by primary human food use (seed, root, fruit or leaf), a number of interesting differences were observed. 
With regard to production constraints, a lack of access to and unavailability of suitable highquality planting material was mentioned most frequently (without correcting for different crop representations within crop categories, as shown in figure 5 ) for root crops ( $28 \%$ of 47 responses, compared with $19 \%$ of 134 responses for all other crop uses). This could reflect issues with the multiplication of these often vegetatively propagated species prior to distribution. Harvesting problems were indicated proportionally as a greater constraint for crops used primarily for seed (13\% of 82 responses, compared with $5 \%$ of 99 responses for all other crop uses). Difficulties with harvesting and threshing of some seed crops are further related in sections 3.3.5 and 3.3.9. Storage problems were mentioned relatively rarely as a constraint for crops used primarily for seed compared to other crops ( $2 \%$ of 82 responses for seed crops compared with $12 \%$ of 99 responses for all other crop uses). This likely reflects the more perishable nature of roots, fruits and leaves after harvest.

With regard to genetic improvement, nutritional value and/or food quality (considered together as a single trait category) was more frequently identified as important for fruit and root crops than for leaf and seed crops ( $15 \%$ of 82 , and $5 \%$ of 97 pooled responses respectively). This may reflect expectations of how particular foods should contribute to diets as much as - or more than - differences in the nutritional composition of foods. For example, some of the new and orphan fruit crops indicated by breeders as requiring nutritional improvement already have excellent nutritional profiles compared with representative plants of other crop groups. Drought tolerance was mentioned more frequently as important for leaf and seed crops than it was for fruit and root crops ( $25 \%$ of 97 , and $7 \%$ of 82 pooled responses respectively). Consistent with responses on production constraints, the need for genetic improvement for harvestability was observed to be relatively greater for seed crops ( $7 \%$ of 82 responses for seed crops and $3 \%$ of 97 pooled responses for other crops). Similarly, the need for genetic improvement for storability was not mentioned for seed crops ( $0 \%$ of 82 responses), while $9 \%$ of 82 pooled responses for fruit and root crops mentioned this target. At first sight, it appears anomalous that genetic improvement in storability was not identified as a target for any leaf crops. However, this may simply indicate that although the storage of perishable leafy vegetables is a clear problem, genetic improvement is not seen as the way to address the issue.

In terms of management interventions, pest and disease control measures were perceived to be relatively less important for root crops than for other crops (11\% of 27 responses for root crops compared to $24 \%$ of 84 pooled responses for all other crops). Harvesting interventions were deemed important only for fruit and seed crops (12\% of 76 responses for all fruit and seed crops compared with $0 \%$ of 35 pooled responses for all other crop categories). The importance of harvest interventions for seed crops is consistent with the production 
constraints for them (discussed above) and sits alongside the need for genetic improvement interventions: breeders see both genetic and agronomic interventions as important for handling seed crops' harvestability constraints.

\subsubsection{Production constraints, traits for genetic improvement and management} interventions for the most frequently mentioned crops

For the four AOCC crops that were commented on by breeders at least four times - Bambara groundnut, finger millet, fonio and okra (see the introduction to section 3.3 and figure 5) - we compiled crop-specific responses from breeders for production constraints, traits for genetic improvement and management interventions; the results are shown in table 1. These indicate the range of responses obtained for each crop. Three of the crops are used primarily for seed: Bambara groundnut is a legume grown for its underground nut; and fonio and finger millet are grasses both grown for their grain. The other, okra, is primarily used for its fruit.

Table 1. Priority production constraints, traits for genetic improvement and management interventions for four AOCC crops.

Priorities are based on the number of breeders' responses (minimum of two mentions).

\begin{tabular}{|c|c|c|c|}
\hline Crop & $\begin{array}{l}\text { Max. three priority } \\
\text { production constraints } \\
\text { (most mentions, in order) }\end{array}$ & $\begin{array}{l}\text { Max. three priority traits/trait } \\
\text { areas for genetic } \\
\text { improvement (most } \\
\text { mentions, in order) }\end{array}$ & $\begin{array}{l}\text { Max. three priority } \\
\text { agronomic management } \\
\text { interventions (most } \\
\text { mentions, in order) }\end{array}$ \\
\hline $\begin{array}{l}\text { Abelmoschus } \\
\text { caillei (Okra) }\end{array}$ & $\begin{array}{l}\text { Pests and diseases; yield; } \\
\text { planting material availability }\end{array}$ & $\begin{array}{l}\text { Yield; pest/disease } \\
\text { resistance/tolerance; } \\
\text { nutritional value/food } \\
\text { quality }\end{array}$ & $\begin{array}{l}\text { Pest/disease control, } \\
\text { including use of integrated } \\
\text { pest management; soil } \\
\text { fertilisation; timing of } \\
\text { harvesting }\end{array}$ \\
\hline $\begin{array}{l}\text { Digitaria exilis } \\
\text { (Fonio) }\end{array}$ & $\begin{array}{l}\text { Harvest and post-harvest } \\
\text { problems, including } \\
\text { shattering and threshing; } \\
\text { planting material availability }\end{array}$ & $\begin{array}{l}\text { Yield; drought tolerance; } \\
\text { ease of harvesting }\end{array}$ & $\begin{array}{l}\text { Seasonal timing of weeding } \\
\text { and harvesting }\end{array}$ \\
\hline $\begin{array}{l}\text { Eleusine } \\
\text { coracana } \\
\text { (Finger millet) }\end{array}$ & $\begin{array}{l}\text { Pests and diseases, } \\
\text { especially blast disease; } \\
\text { harvest and post-harvest } \\
\text { problems, including } \\
\text { threshing; weeds }\end{array}$ & $\begin{array}{l}\text { Pest/disease } \\
\text { resistance/tolerance, } \\
\text { especially to blast disease }\end{array}$ & $\begin{array}{l}\text { Establishment methods, } \\
\text { especially use of row } \\
\text { planting; mechanization of } \\
\text { harvesting and threshing }\end{array}$ \\
\hline $\begin{array}{l}\text { Vigna } \\
\text { subterranea } \\
\text { (Bambara } \\
\text { groundnut) }\end{array}$ & $\begin{array}{l}\text { Planting material } \\
\text { availability; pests and } \\
\text { diseases; drought }\end{array}$ & $\begin{array}{l}\text { Pest/disease } \\
\text { resistance/tolerance; yield; } \\
\text { drought tolerance; early } \\
\text { maturity (last two tied with } \\
\text { equal mentions) }\end{array}$ & $\begin{array}{l}\text { Soil fertilization; seasonal } \\
\text { timing, including of planting, } \\
\text { weeding and harvesting; } \\
\text { pest/disease control, } \\
\text { including during storage }\end{array}$ \\
\hline
\end{tabular}




\subsubsection{Likelihood of success of genetic improvement and management interventions}

The survey asked respondents commenting on specific AOCC crops to indicate from among different options what they considered the likelihood of success for the genetic improvement and agronomic management interventions they had suggested (see sections 3.3.2 and 3.3.3). A review of the 53 breeders' responses for specific AOCC crops, without any correction for the different representations of the various crops in the results (see figure 5), indicated that breeders consider management actions to have the highest likelihood of success. However, breeders also indicated high potential for successful action on trait genetic improvement (figure 9). Overall, $63 \%$ of management interventions mentioned were considered to have high potential, compared with $52 \%$ of genetic improvement interventions - indicating a majority in both cases.

Figure 9. Specific new and orphan crops: likelihood of success of interventions.

(a) genetic improvement interventions and (b) management interventions.

(a)

$\square$ High
$\square$ Medium
$\square$ Low
$\square$ No opinion

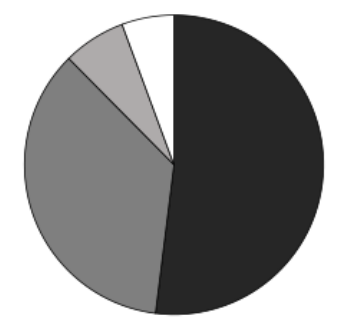

(b)

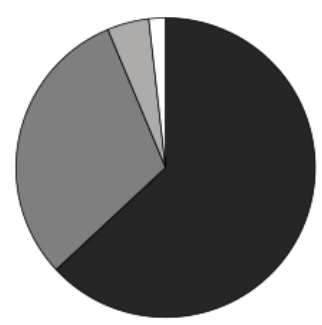

\subsubsection{Other insights for crop improvement}

The survey asked respondents commenting on specific AOCC crops for additional insights into improving crop production; this question elicited only limited information. Some breeders suggested that non-food uses such as medicine or fibre should be enhanced to promote crops. Others mentioned the application of chemicals to promote seed germination and flowering, to have potential. 


\subsubsection{Particular challenges and opportunities presented by climate change}

When queried about the particular challenges and opportunities presented by climate change for specific AOCC crops, respondents mentioned a lack of knowledge about genetic variation in crops' tolerances to drought and flooding, and the limited information available on crops' genotype-by-environment interactions. Enhanced pest and disease pressures due to climate change were also a major concern.

In terms of opportunities, respondents considered several new and orphan crops to be drought-tolerant species that could be suitable for production in drier or drought-prone conditions, which may prevail due to climate change. Breeders also recognized carbon sequestration opportunities to mitigate climate change for woody perennial species. In addition, respondents noted the diversification opportunities provided by new and orphan crops, which could spread the risks created by more variable weather patterns linked to climate change. It is notable that while breeders indicated several new and orphan crops as conferring drought-tolerant cropping options, many also acknowledged drought as a production constraint for new and orphan crop plants (see figures 2 and 6). This apparent anomaly probably reflects the wide range of drought tolerances among new and orphan crops as a group: while some crops are already highly drought tolerant, others need to be made more tolerant.

\subsubsection{Particular harvesting and processing challenges}

Breeders were asked about particular problems in harvesting and processing of specific AOCC crops. The range of responses indicated that these problems are particularly relevant for seed crops (see section 3.3.4). Problems include: shattering; the small size of their seed (grain), which leads to harvest and cleaning (threshing) difficulties; and the labour costs of manual harvesting (see table 1 for responses on finger millet and fonio).

Also mentioned by breeders was the large size (stature) of some perennials, which makes it difficult to reach the crop for harvest. Other responses included crop damage caused by harvesting, problems identifying the crop's point of maturity (readiness for harvest) and some plants' extended maturation periods (this necessitates returning to the crop for multiple harvests, which can be labour inefficient).

Post-harvest extraction of the edible portion of crops (e.g. pulp from fruit, fat from seed) and high perishability during storage were also mentioned as specific problems. 


\subsection{Linking with food scientists and agricultural economists}

Breeders were asked if they worked closely with food scientists or economists on particular crops (whether new and orphan crops, or other crops). Of the 67 breeders who undertook the survey, 64 responded on this topic. Of these, 29 reported working closely with economists $(45 \%)$ and 25 with food scientists (39\%). These figures suggest there is room for greater collaboration within wider food mainstreaming efforts. A fuller understanding of the extent of collaboration among disciplines requires further exploration. In our survey, breeders were only asked about "close" collaborations: more distant but still useful interactions between breeders, economists and food scientists may not have been captured.

Of the crops that breeders reported they had worked closely with food scientists on, nine were on the AOCC list: Bambara groundnut, banana, cocoyam, fluted gourd, green bean, sweet bush mango, sweet potato, taro and shea. These crops represent a range of food uses and a mix of annual and perennial species. The work undertaken by food scientists on these crops related to foods' sensory properties, nutritional compositions and new processing opportunities. In the last case, work included on ingredient substitution of new and orphan crops for other less nutritious crops in processed food production.

Of the crops that breeders reported working closely with economists on, 15 were on the AOCC list: African plum, banana, bitter yam, cocoyam, fluted gourd, geocarpa groundnut, green bean, groundnut tree, mung bean, okra, sweet bush mango, sweet potato, shea, taro and watermelon. Again, these plants represent a range of food uses and diverse plant biologies. Economists' work on these crops included research on the economics of production and value chain development. This work also focused on marketing options and the assessment of consumers' preferences.

In their survey responses, breeders named a number of the food scientists and economists that they worked with and provided contact details for these individuals. Future contact with these individuals would provide opportunities to explore further how to mainstream new and orphan crops into African food systems. In particular, it would help to address key consumption and livelihood issues along with production concerns. 


\section{Conclusions and recommendations}

This survey of African plant breeders has explored production constraints for new and orphan crops on the continent, and has highlighted opportunities for interventions at the genetic improvement and agronomic management levels. It further reveals the competencies and capabilities needed to remove obstacles to the more efficient production of new and orphan crops in Africa. As indicated in a previous ICRAF working paper (Dawson et al., 2018), identifying key traits for genetic improvement of new and orphan crops is crucial to mainstream their production. Based on survey responses, critical capabilities to address the yield gap include disease screening, agronomic training for farmers (i.e. extension), and the provision of high-quality planting material of locally adapted cultivars. While the survey does not directly address the constraints breeders face as obstacles to developing improved cultivars, their responses suggest a need for access to diverse germplasm that has been characterized for traits of interest such as drought tolerance, shattering resistance and disease resistance.

The findings of our survey indicate that pest and disease susceptibility, and lack of access to (and availability of) high-quality planting material constitute critical barriers to enhanced new and orphan crop production. Our analysis also shows that production constraints, key traits for genetic improvement and the necessary agronomic management interventions vary by crop food use. Product targets and management options can be further disaggregated within the data to explore context specificity in greater depth. Overall, breeders indicated that there was high likelihood of genetic improvement and management interventions being successful.

Our current analysis needs to be built upon by further evaluating the requirements of producers, consumers and retailers, since developing specific breeding targets requires the collaboration of all value-chain stakeholders to meet the demands of local geographies and markets. For example, although breeders have a good perspective on production issues, their views may not always align with those of farmers. A more nuanced assessment of production constraints would thus require direct discussions with producers. The wider assessment of stakeholders would enable more effective targeting of AOCC trait discovery, and ensure better alignment among crop improvement objectives, breeding approaches and planting material delivery mechanisms (Lillesø et al., 2011). However, the advantage conveyed by surveying breeders to gain production insights in our survey was that, within a short timeframe, the research team was able to access a vast reservoir of knowledge relevant for improving new and orphan crops, in a cost-efficient manner. 
The need for follow-up with breeders is indicated throughout this report, particularly to understand constraints to planting material access and availability. This topic has been explored more widely in the past for perennial orphan crops than for annuals (Lillesø et al., 2011), suggesting a particular focus may be required on the latter. Future surveys of breeders should also consider the specific resources they need (the required facilities and competencies, etc.) to develop improved cultivars with desired traits. In future evaluations, we also recommend that research teams contact the food scientists and economists identified in this survey who work on specific new and orphan crops. Such contact would further inform the mainstreaming of new and orphan crop production activities into wider food systems. Linking with food scientists would for example allow the further exploration of traits that increase the processability of new and orphan crops (Bakare et al., 2016). Linking with economists would provide more information on traits influencing the profitability of production (Blare and Donovan, 2018). Both these issues are crucial if African food systems are to become more nutritious and sustainable in the context of current regional challenges and social, demographic and economic trends (Dawson et al., 2018). 


\section{References}

AfPBA. 2019. The University of California Davis African Plant Breeding Academy. http://pba.ucdavis.edu/PBA in Africal

African Union. 2014. Malabo declaration on accelerated agricultural growth and transformation for shared prosperity and improved livelihoods. African Union, Addis Ababa, Ethiopia.

AOCC. 2019. The African Orphan Crops Consortium. http://africanorphancrops.org/

Bakare AH, Osundahunsi OF, Olusanya JO. 2016. Rheological, baking, and sensory properties of composite bread dough with breadfruit (Artocarpus communis Forst) and wheat flours. Food Science \& Nutrition, 4, 573-587.

Blare T, Donovan J. 2018. Building value chains for indigenous fruits: lessons from camucamu in Peru. Renewable Agriculture and Food Systems 33, 6-18.

Dawson IK, Hendre P, Powell W, Sila D, McMullin S, Simons T, Revoredo-Giha C, Odeny DA, Barnes AP, Graudal L et al. 2018. Supporting human nutrition in Africa through the integration of new and orphan crops into food systems: placing the work of the African Orphan Crops Consortium in context. ICRAF Working Paper No. 276. The World Agroforestry Centre, Nairobi, Kenya.

Economist. 2017. No crop left behind: improving the plants that Africans eat and breeders neglect. The Economist. https://www.economist.com/science-andtechnology/2017/11/23/improving-the-plants-that-africans-eat-and-breeders-neglect

Kessides C. 2005. The urban transition in Sub-Saharan Africa: implications for economic growth and poverty reduction. Africa Region, Working Paper Series No. 97. The World Bank, Washington DC, USA.

Khoury CK, Bjorkman AD, Dempewolf H, Ramirez-Villegas J, Guarino L, Jarvis A, Rieseburg LH, Struik PC. 2014. Increasing homogeneity in global food supplies and the implications for food security. Proceedings of the National Academy of Sciences USA, 111, 4001-4006. 
Lillesø J-PB, Graudal L, Moestrup S, Kjær ED, Kindt R et al. 2011. Innovation in input supply systems in smallholder agroforestry: seed sources, supply chains and support systems.

Agroforestry Systems, 83, 347-359

WACCI. 2019. The West Africa Centre for Crop Improvement. http://www.wacci.edu.gh/

Walker T, Alene A, Ndjeunga J, Labarta R, Yigezu Y, Diagne A, Andrade R, Muthoni Andriatsitohaina R, De Groote H, Mausch K et al. 2014. Measuring the effectiveness of crop improvement research in sub-Saharan Africa from the perspectives of varietal output, adoption, and change: 20 crops, 30 countries, and 1150 cultivars in farmers' fields. Report of the Standing Panel on Impact Assessment. CGIAR Independent Science and Partnership Council Secretariat, Rome, Italy. 
Appendix 1. Online questionnaire used to obtain information from plant breeders

\section{(Explanatory notes to the online survey are highlighted in blue.)}

\section{Improving the production of new and orphan crops in Africa}

There has been renewed interest recently in integrating new and orphan crops into African food systems. This survey collects information on the production constraints faced by these crops, and how these constraints can be addressed.

For current purposes, we consider new and orphan crops as under-researched annual crops or perennial crops, including trees, which have potential for greater use in African food systems. You have been contacted to complete this survey because of your work on crop production in Africa, whether this is on major crops and/or on new and orphan crops. The survey collects some general information on orphan crop production and then considers some specific crops that the African Orphan Crops Consortium considers important.

Participants in this survey will be acknowledged when results are presented and will receive a report summarising the collected information.

Depending on the level of detail of information you hold, this survey will probably take between 20 minutes and one hour to complete.

We thank you for your participation. The World Agroforestry Centre (ICRAF) and Scotland's Rural College (SRUC).

\section{Information about you}

Please provide your name, email address, area of expertise, institution and all the crops you personally currently work on or in the past have worked on (it does not matter whether these are new and orphan crops or other crops):

Your name

[Text field response]

Your email

[Text field response]

Your institution

[Text field response] 
Your area of expertise

The Crops you currently and have, in the past, worked on

Please tick this box if you do not want your details to be included in a summary report of this survey

[N]

Information on new and orphan crops in general

Considering new and orphan crops 'in the round' (as a category of crops), what do you consider to be the most important production constraints faced by African farmers? Please list up to the three most important constraints:

Constraint 1 [Text field response]

Constraint 2 [Text field response]

Constraint 3 [Text field response]

Apart from production constraints, what do you consider to be the other major constraints that limit the use of new and orphan crops 'in the round' as foods or food ingredients in Africa? Please list up to the three most important constraints:

Constraint 1 [Text field response]

Constraint 2 [Text field response]

Constraint 3 [Text field response]

Do you think new and orphan crops will be of less, equal or more importance as foods within Africa in 20 years' time?

(Only one answer to the below options was possible.)

Less Importance

Equal Importance

More Importance

No Opinion

Could you explain your answer?
$[\mathrm{Y}]$

$[\mathrm{Y}]$

$[\mathrm{Y}]$

[Y]

[Text field response] 


\section{Specific information on new and orphan crops}

The below is a list of the 101 new and orphan crops that the African Orphan Crops

Consortium considers as priorities for supporting human nutrition.

\author{
Abelmoschus caillei (Okra) \\ Adansonia digitata (Baobab) \\ Adansonia kilima (Baobab) \\ Allanblackia floribunda (Vegetable tallow tree) \\ Allium cepa (Onion) \\ Amaranthus blitum (Amaranth) \\ Amaranthus cruentus (Grain amaranth) \\ Amaranthus tricolor (Vegetable amaranth) \\ Anacardium occidentale (Cashew) \\ Annona reticulata (Custard apple) \\ Annona senegalensis (Wild custard apple) \\ Artocarpus altilis (Breadfruit) \\ Artocarpus heterophyllus (Jack tree) \\ Balanites aegyptiaca (Balanites) \\ Basella alba (Vine spinach) \\ Boscia senegalensis (Aizen, nabedega) \\ Brassica carinata (Ethiopian mustard) \\ Canarium madagascariense (Canarium nut) \\ Carica papaya (Papaya) \\ Carissa spinarum (Carissa) \\ Casimiroa edulis (White sapote) \\ Cassia obtusifolia (Sickle senna) \\ Celosia argentea (Celosia) \\ Chrysophyllum cainito (Star apple) \\ Citrullus lanatus (Watermelon) \\ Cleome gynandra (Spider plant) \\ Cocos nucifera (Coconut) \\ Colocasia esculenta (Taro) \\ Corchorus olitorius (Jute mallow) \\ Crassocephalum rubens (Yoruban bologi) \\ Crotalaria juncea (Sunn hemp) \\ Crotalaria ochroleuca (Rattlebox) \\ Cucumis metuliferus (Horned melon) \\ Cucurbita maxima (Pumpkin) \\ Cyphomandra betacea (Cape tomato) \\ Dacryodes edulis (African plum) \\ Detarium senegalense (Sweet detar) \\ Digitaria exilis (Fonio) \\ Dioscorea alata (Yam) \\ Dioscorea dumetorum (Bitter yam) \\ Dioscorea rotundata (Yam) \\ Diospyros mespiliformis (African persimmon) \\ Dovyalis caffra (Kei apple) \\ Elaeis guineensis (Oil palm) \\ Eleusine coracana (Finger millet) \\ Ensete ventricosum (Enset) \\ Faidherbia albida (Acacia [apple-ring]) \\ Garcinia livingstonei (African mangosteen) \\ Garcinia mangostana (Mangosteen) \\ Gnetum africanum (African gnetum) \\ Hibiscus sabdariffa (Roselle)
}

Icacina oliviformis (False yam)

Ipomoea batatas (Sweet potato [leaves])

Irvingia gabonensis (Sweet bush mango)

Lablab purpureus (Lablab bean)

Landolphia spp. (Gum vines)

Lannea microcarpa (Tree grape)

Lens culinaris (Lentil)

Macadamia ternifolia (Macadamia)

Macrotyloma geocarpum (Geocarpa groundnut)

Mangifera indica (Mango)

Momordica charantia (Bittergourd)

Moringa oleifera (Drumstick tree)

Morus alba (Mulberry)

Musa acuminata AAA Group (Banana)

Musa balbisiana (Banana)

Musa x paradisiaca AAB Group (Plantain)

Opuntia monacantha (Prickly pear)

Parinari curatellifolia (Mobola plum)

Parkia biglobosa (African locust bean)

Passiflora edulis (Passion fruit)

Persea americana (Avocado)

Phaseolus lunatus (Lima bean)

Phaseolus vulgaris (Green bean)

Plectranthus esculentus (African potato)

Plectranthus rotundifolius (African potato)

Psidium guajava (Guava)

Ricinodendron heudelotii (Groundnut tree)

Saba comorensis (Rubber vine)

Sclerocarya birrea (Marula)

Solanum aethiopicum (African eggplant)

Solanum scabrum (African nightshade)

Sphenostylis stenocarpa (Yam bean)

Strychnos spinosa (African orange)

Syzygium guineense (Water berry)

Talinum fruticosum (Ceylon spinach)

Tamarindus indica (Tamarind)

Telfairia occidentalis (Fluted gourd)

Tylosema esculentum (Marama bean)

Uapaca kirkiana (Wild loquat)

Vangueria infausta (African medlar)

Vangueria madagascariensis (African medlar)

Vicia faba (Faba bean)

Vigna radiata (Mung bean)

Vigna subterranea (Bambara groundnut)

Vitellaria paradoxa (Shea)

Vitex doniana (Chocolate berry)

Xanthosoma sagittifolium (Elephant ear)

Xanthosoma spp. (Cocoyam, Arrowroot)

Ximenia caffra (Sour plum)

Ziziphus spp. (Jujube) 
Please indicate a crop where you think you have sufficient knowledge to comment on its production (regardless of whether or not you currently work directly on or in the past have worked directly on the crop). On the next page you will be asked for specific information on this crop. (If you cannot comment on any of these specific crops, please tick the box at the bottom of the page).

[Y] (Only one crop could be chosen for comment at any one time, but each respondent was allowed to provide information on up to five specific crops by cycling through a set of questions for each crop.)

I am not able to comment on any of these crops $[\mathrm{N}]$

(When able to respond on a specific crop [not $\mathrm{N}$ above] the below questions were presented:)

Considering this particular crop, what do you consider to be the most important production constraints faced by African farmers? Please list up to the three most important production constraints and be as specific as possible (e.g., specific harvesting problem, susceptibility to a particular disease, lack of access to a particular input):

Production Constraint $1 \quad$ [Text field response]

Production Constraint $2 \quad$ [Text field response]

Production Constraint $3 \quad$ [Text field response]

Considering this particular crop, what do you consider to be the key traits for genetic improvement through selection and/or breeding to support African production and use? Please list up to the three most important traits for genetic improvement and be as specific as possible (e.g., breeding tolerance to a specific disease, reducing the amount of a particular anti-nutrient, adapting to a particular environmental constraint):

Trait for genetic improvement 1 [Text field response]

Trait for genetic improvement 2 [Text field response]

Trait for genetic improvement 3 [Text field response]

In your opinion, what is the potential for genetic improvement of each of the above traits?

(For each trait, only one answer to the below options was possible.)

No opinion

[Y] 
Low potential $\quad[\mathrm{Y}]$

Medium potential [Y]

High potential $\quad[\mathrm{Y}]$

Are you aware of a breeding or other genetic improvement programme(s) for this crop? If so, please describe briefly (e.g., who is involved, what the purpose of the programme is, who funds the work)

\section{[Text field response]}

Considering this particular crop, what do you consider to be the key agronomic (management) interventions to support African production and use? Please list up to the three most important agronomic interventions and be as specific as possible (e.g., particular weed prevention regime, particular harvesting method, particular pest prevention approach):

Agronomic Intervention 1 [Text field response] Agronomic Intervention 2 [Text field response]

Agronomic Intervention 3 [Text field response]

In your opinion, what is the potential for introducing each of the above agronomic interventions?

\section{(For each agronomic intervention, only one answer to the below options was possible.)}

$\begin{array}{ll}\text { No opinion } & {[\mathrm{Y}]} \\ \text { Low potential } & {[\mathrm{Y}]} \\ \text { Medium potential } & {[\mathrm{Y}]} \\ \text { High Potential } & {[\mathrm{Y}]}\end{array}$

If you have any other insights to share on improving the production of this crop please share them here

\section{[Text field response]}

For this particular crop, are there challenges or opportunities presented by climate change?

\section{[Text field response]}


For this particular crop, are there any particular problems in harvesting and processing?

\section{[Text field response]}

Could you comment on the production of another crop? (Note if answering yes you will be taken back to the AOCC orphan crops list. You will in total be given the opportunity to comment on a maximum of 5 crops)

[Y/N] (Response determined whether returned to the African Orphan Crops Consortium crop list $[\mathrm{Y}]$ or continued to the below questions $[\mathrm{N}]$.)

\section{Linking with food scientists and agricultural economists}

For the particular crop or crops (whether these are new and orphan crops or other crops, including maize, rice, etc.) that you personally work on, do you work closely with food scientists (e.g., food processing specialists, nutritionists)?

\section{$[\mathrm{Y} / \mathrm{N}]$}

If yes, please indicate the name(s) of the particular crop(s) you work on with food scientists, briefly what the work involves (e.g. improving food processing, product substitution etc.), the name(s) of the scientist(s), and if possible their contact email(s):

Crops

[Text field response]

What the work involves [Text field response]

Name of the scientists

\section{[Text field response]}

For the particular crop or crops (whether new and orphan crops or other crops, including maize, rice, etc.) that you personally work on, do you work closely with economists (e.g. in improving value chains, in providing market information etc.)?

$[\mathrm{Y} / \mathrm{N}]$

If yes, please indicate the name(s) of the particular crop(s) you work on with economists, briefly what the work involves, the name(s) of the economist(s), and if possible their contact email(s):

Crops

[Text field response] 
What the work involves

[Text field response]

Name of the economists

[Text field response] 


\section{Appendix 2. List of survey respondents who wished to be identified (by country)}

\author{
Name (as given by the respondent) \\ Patrick Van Damme \\ Drabo Inoussa \\ Benoit Joseph Batieno \\ Ouedraogo Nofou \\ SOME Koussao \\ TRAORE VAL. STANISLAS EDGAR \\ MAFOUASSON APALA HORTENSE \\ Ann Degrande \\ Atemkeng epse Nkoumki Maureen Fonji \\ Gonne SOBDA \\ Dowiya Benjamin Nzawele \\ Fatma Awad Hussein \\ Yonas Moges gelaw \\ Fekadu Gurmu \\ Vivian Oduro \\ Ernest Baafi \\ Matilda Bissah \\ Nicholas Denwar \\ Samuel Oppong Abebrese \\ Alice Kosgei \\ Pascal Ojwang \\ Mathews M Dida \\ Regina Tende \\ Ruth N. Musila \\ Lawrent Pungulani \\ Dramane Sako \\ SAFIATOU SANGARE \\ Kalinganire Antoine \\ Ousmane Sanogo \\ Catherine Dembele \\ Oumarou Souleymane \\ Mamadou Coulibaly \\ Laouali Mahamane Nasser \\ Ahmadou Issaka \\ Mamadou Ibrahim Aissata \\ Adesike Oladoyin Kolawole \\ Afolayan Gloria \\ Damian Ndubuisi NJOKU \\ ELOHOR MERCY DIEBIRU \\ Dorcas Olubunmi Ibitoye \\ AMADI CHARLES \\ Daniel Adewale \\ Bunmi Olasanmi \\ Friday Nwalo Nweke \\ Ndacyayisenga Theophile \\ Innocent Habarurema \\ Abe Gerrano \\ Mayada Beshir \\ Samson Gwali \\ Busiso Olga Mavankeni
}

Institutional affiliation (as given by the respondent)

Ghent University, Belgium

INERA, Burkina Faso

INERA, Burkina Faso

Institute of Environment and Agricultural Research, Burkina Faso

INERA, Burkina Faso

INERA, BURKINA FASO

Institute of agricultural research for development, Cameroon

ICRAF, Cameroon Office, Cameroon

Institute of Agric. Research for Development (IRAD), Cameroon

IRAD, Cameroon

Institut Facultaire des Sciences Agronomiques de Yangambi, DRC

Field Crops Research Institute - Rice Department, Egypt

Haramaya University, Ethiopia

South Agricultural Research Institute, Ethiopia

Biotechnology and Nuclear Agriculture Research Institute, Ghana

CSIR-Crops Research Institute, Ghana

CSIR-Plant Genetic Resources Research Institute, Ghana

CSIR-Savanna Agricultural Research Institute, Tamale, Ghana

CSIR-Savanna Agricultural Research Institute, Ghana

Machakos University, Kenya

Egerton University, Kenya

Maseno University, Kenya

Kenya Agricultural and Livestock Research Organization, Kenya

Kenya Agricultural and Livestock Research Organisation, Kenya

Malawi Plant Genetic Resources Centre, Malawi

Institut d'Économie Rurale, Mali

Institut D'Economie Rurale (IER), Mali

ICRAF, Mali Office, Mali

IER, Mali

ICRAF/SAHEL, Regional Office, Mali

INRAN (National Agricultural Research Institute of Niger), Niger

IER, Niger

INRAN, Niger

Institut National de la Recherche Agronomique du Niger, Niger

INRAN, Niger

Ladoke Akintola University of Technology, Ogbomoso, Nigeria

National Center for Genetic Resources and Biotechnology, Nigeria

National Root Crops Research Institute (NRCRI), Umudike, Nigeria

International Institute for Tropical Agriculture, Nigeria

National Horticultural Research Institute, Ibadan, Nigeria

NATIONAL ROOT CROPS RESEARCH INSTITUTE, NIGERIA

Federal University Oye-Ekiti, Nigeria

University of Ibadan, Nigeria

Federal University, Ndufu-Alike Ikwo, Ebonyi State, Nigeria

Rwanda Agriculture Board (RAB), Rwanda

Rwanda Agriculture Board (RAB), Rwanda

Agricultural Research Council, South Africa

Agricultural Research Corporation (ARC), Sudan

National Forestry Resources Research Institute (NaFORRI), Uganda

Crop Breeding Institute, Zimbabwe 


\section{Working Paper Series}

240. The national agroforestry policy of India: experiential learning in development and delivery phases. http://dx.doi.org/10.5716/WP16143.PDF

241. Agroforestry and forestry in Sulawesi series: Livelihood strategies and land-use system dynamics in Gorontalo. http://dx.doi.org/10.5716/WP16157.PDF

242. Seri Agroforestri dan Kehutanan di Sulawesi: Strategi mata pencaharian dan dinamika system penggunaan lahan di Gorontalo. http://dx.doi.org/10.5716/WP16158.PDF

243. Ruang, Gender dan Kualitas Hidup Manusia: Sebuah studi Gender pada komunitas perantau dan pengelola kebun di Jawa Barat. http://dx.doi.org/10.5716/WP16159.PDF

244. Gendered knowledge and perception in managing grassland areas in East Sumba, Indonesia. http://dx.doi.org/10.5716/WP16160.PDF

245. Pengetahuan dan persepsi masyarakat pengelola padang aavana, Sebuah Kajian Gender di Sumba Timur. http://dx.doi.org/10.5716/WP16161.PDF

246. Dinamika Pengambilan Keputusan pada komunitas perantau dan pengelola kebun di Jawa Barat. http://dx.doi.org/10.5716/WP16162.PDF

247. Gaharu (eaglewood) domestication: biotechnology, markets and agroforestry options. http://dx.doi.org/10.5716/WP16163.PDF

248. Marine habitats of the Lamu-Kiunga coast: an assessment of biodiversity value, threats and opportunities. http://dx.doi.org/10.5716/WP16167.PDF

249. Assessment of the biodiversity in terrestrial landscapes of the Witu protected area and surroundings, Lamu County, Kenya. http://dx.doi.org/10.5716/WP16172.PDF

250. An ecosystem services perspective on benefits that people derive from biodiversity of Coastal forests in Lamu County, Kenya http://dx.doi.org/10.5716/WP16173.PDF

251. Assessment of the biodiversity in terrestrial and marine landscapes of the proposed Laga Badana National Park and surrounding areas, Jubaland, Somalia.

http://dx.doi.org/10.5716/WP16174.PDF 
2017

252. Preferensi Petani terhadap Topik Penyuluhan dan Penyebaran Informasi Agroforestri di Indonesia http://dx.doi.org/10.5716/WP16181.PDF

253. Seri Agroforestri dan Kehutanan di Sulawesi: Keanekaragaman hayati jenis pohon pada hutan rakyat agroforestri di DAS Balangtieng, Sulawesi Selatan http://dx.doi.org/10.5716/WP16182.PDF

254. Potensi dan Tantangan dalam Pengembangan Skema Ko-Investasi Jasa Lingkungan di Kabupaten Buol, Indonesia. http://dx.doi.org/10.5716/WP17008.PDF

255. Keragaman Jenis Pohon dan Pemanfaatannya oleh Masyarakat di Kabupaten Buol, Indonesia. http://dx.doi.org/10.5716/WP17009.PDF

256. Kerentanan dan preferensi sistem pertanian petani di Kabupaten Buol, Indonesia http://dx.doi.org/10.5716/WP17010.PDF

257. Dinamika Perubahan Penggunaan/Tutupan Lahan Serta Cadangan Karbon di Kabupaten Buol, Indonesia. http://dx.doi.org/10.5716/WP17011.PDF

258. The effectiveness of the volunteer farmer trainer approach vis-à-vis other information sources in dissemination of livestock feed technologies in Uganda.

http://dx.doi.org/10.5716/WP17104.PDF

259. Agroforestry and forestry in Sulawesi series: Impact of agricultural-extension booklets on community livelihoods in South and Southeast Sulawesi.

http://dx.doi.org/10.5716/WP17125.PDF

260. Petani Menjadi Penyuluh, Mungkinkah? Sebuah Pendekatan Penyuluhan dari Petani ke Petani di Kabupaten Sumb Timur. http://dx.doi.org/10.5716/WP17145.PDF

261. Dampak Perubahan Tutupan Lahan terhadap Kondisi Hidrologi di Das Buol, Kabupaten Buol, Sulawesi Tengah: Simulasi dengan Model Genriver http://dx.doi.org/10.5716/WP17146.PDF

262. Analisis Tapak Mata Air Umbulan, Pasuruan, Jawa Timur. Kajian elemen biofisik dan persepsi masyarakat. http://dx.doi.org/10.5716/WP17147.PDF 
263. Planned comparisons demystified. http://dx.doi.org/10.5716/WP17354.PDF

264. Soil health decision support for NERC digital soil platforms: A survey report http://dx.doi.org/10.5716/WP17355.PDF

265. Seri Pembangunan Ekonomi Pedesaan Indonesia: Menanam di bukit gundul: Pengetahuan masyarakat lokal dalam upaya restorasi lahan di Sumba Timur.

http://dx.doi.org/10.5716/WP17356.PDF

266. Tree diversity and carbon stock in three districts of Kutai Timur, Pasir and Berau, East Kalimantan http://dx.doi.org/10.5716/WP17357.PDF

267. Tree Diversity and Carbon Stock in Various Land Use Systems of Banyuasin and Musi Banyuasin Districts, South Sumatera http://dx.doi.org/10.5716/WP17358.PDF

268. Tree diversity and carbon stock in various land cover systems of Jayapura, Jayawijaya and Merauke Districts, Papua Province http://dx.doi.org/10.5716/WP17359.PDF

269. Modelling tree production based on farmers' knowledge: case for kapok (Ceiba pentandra) and candlenut (Aleurites mollucana) under various agroforestry scenarios. http://dx.doi.org/10.5716/WP17361.PDF

270. The Impact of Land Cover and Climate Change on Present and Future Watershed Condition. Study case: Tugasan, Alanib and Kulasihan Sub-watershed of Manupali Watershed, Lantapan, Bukidnon, Philippines. http://dx.doi.org/10.5716/WP17362.PDF

271. Tree Diversity and Above-ground Carbon Stock estimation in Various Land use Systems in Banjarnegara, Banyumas and Purbalingga, Central Java.

http://dx.doi.org/10.5716/WP17363.PDF

272. Agroforestry and Forestry in Sulawesi series: Landscape Management Strategies in Sulawesi: Review of Intervention Options. http://dx.doi.org/10.5716/WP17364.PDF

273. Household Food-Security and Nutritional Status of Women and Children in Buol Regency, Central Sulawesi, Indonesia. http://dx.doi.org/10.5716/WP17365.PDF

274. Palm oil expansion in tropical forest margins or sustainability of production? Focal issues of regulations and private standards. http://dx.doi.org/10.5716/WP17366.PDF 
$\underline{2018}$

275. Decision analysis methods guide: Agricultural policy for nutrition

http://dx.doi.org/10.5716/WP18001.PDF

276. Supporting human nutrition in Africa through the integration of new and orphan crops into food systems: Placing the work of the African Orphan Crops Consortium in context.

http://dx.doi.org/10.5716/WP18003.PDF

277. Seri Pembangunan Ekonomi Pedesaan Indonesia. Pilihan Manajemen Budidaya Kacang Tanah sebagai Upaya untuk Memperbaiki Penghidupan Masyarakat Haharu.

http://dx.doi.org/10.5716/WP18004.PDF

278. Estudio de línea de base CCAFS a nivel de hogar en Nicaragua y Costa Rica

Fase de diagnóstico del estudio: "Contribución de la diversidad arbórea a los medios de vida para la adaptación y la mitigación al cambio climático

http://dx.doi.org/10.5716/WP18005.PDF

279. Understanding tree cover transition, drivers and stakeholder perspectives for effective landscape governance. A case study in Na Nhan commune, Dien Bien province, Vietnam. http://dx.doi.org/10.5716/WP18006.PDF

280. El Sistema "Quesungual”: Agroforestería y manejo de suelos para la producción de maíz y frijol en laderas. http://dx.doi.org/10.5716/WP18007.PDF

281: Probabilistic Decision Modelling to Determine Impacts on Natural Resource Management and Livelihood Resilience in Marsabit County, Kenya.

http://dx.doi.org/10.5716/WP18008.PDF

282. Shifting discourse, shifting power: how is climate change mitigation and justice negotiated in Indonesia? http://dx.doi.org/10.5716/WP18009.PDF

283. Result of Land Use Planning and Land Administration (LULA) Implementation in South Sumatra, East Kalimantan, Central Java and Papua http://dx.doi.org/10.5716/WP18010.PDF

284. Farmers' preferences for training topics and dissemination of agroforestry information in Indonesia. http://dx.doi.org/10.5716/WP18015.PDF 
285. CSA-Diagnostic (CSA-Dx): A primer for investigating the 'climate-smartness' of ag technologies http://dx.doi.org/10.5716/WP18020.PDF

286. An analysis of the vulnerability of poor communities in Yunnan Province, China http://dx.doi.org/10.5716/WP18021.PDF

287. Gendered space and quality of life: gender study of out-migration and smallholding agroforestry communities in West Java Province, Indonesia.

http://dx.doi.org/10.5716/WP18024.PDF

288: Evaluation of UTZ certification coffee businesses in Guatemala, Honduras and Nicaragua. http://dx.doi.org/10.5716/WP18028.PDF

289. Agroforestry species of Peru: annotated list and contribution to prioritization for genetic conservation. http://dx.doi.org/10.5716/WP18029.PDF

290. Indonesia Rural Economic Development Series.Growing plants on a barren hill: local knowledge as part of land restoration in Sumba Timur, Indonesia.

http://dx.doi.org/10.5716/WP18030.PDF

291. Assessing the Downstream Socioeconomic Impacts of Agroforestry in Kenya http://dx.doi.org/10.5716/WP18033.PDF

\section{$\underline{2019}$}

292: Los árboles fuera del bosque en la NAMA forestal de Colombia. Elementos conceptuales para su contabilización. http://dx.doi.org/10.5716/WP19002.PDF

293: Gender and Adaptation: An Analysis of Poverty and Vulnerability in Yunnan, China. DOI: http://dx.doi.org/10.5716/WP19004.PDF

294: Tree Cover on Agricultural Land in the Asia Pacific Region. DOI: http://dx.doi.org/10.5716/WP19005.PDF

295: What do we really know about the impacts of improved grain legumes and dryland cereals? A critical review of 18 impact studies DOI: http://dx.doi.org/10.5716/WP19006.PDF 
World Agroforestry (ICRAF) is a centre of scientific and development excellence that harnesses the benefits of trees for people and the environment. Leveraging the world's largest repository of agroforestry science and information, we develop knowledge practices, from farmers' fields to the global sphere, to ensure food security and environmental sustainability.

ICRAF is the only institution that does globally significant agroforestry research in and for all of the developing tropics. Knowledge produced by ICRAF enables governments, development agencies and farmers to utilize the power of trees to make farming and livelihoods more environmentally, socially and economically sustainable at multiple scales.

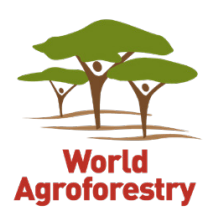

United Nations Avenue, Gigiri • PO Box 30677 • Nairobi, $00100 \cdot$ Kenya Telephone: +254207224000 or via USA +1 6508336645 Fax: +254207224001 or via USA +1 6508336646 Email: worldagroforestry@cgiar.org•www.worldagroforestry.org 